\title{
The Analysis of Teachers' Competence in Participating the In-Service Training Program of Inclusive Education in Indonesia
}

\author{
Abdul Salim ${ }^{1}$ \\ ${ }^{1}$ Master Program in Special Education, Universitas Sebelas Maret of Surakarta, Central Java, Indonesia \\ Correspondence: Abdul Salim, on Jl. Ir. Sutami No.118C, Pucangsawit, Jebres, City of Surakarta, Central Java \\ 57125, Indonesia. E-mail: salimchoiri@fkip.uns.ac.id
}

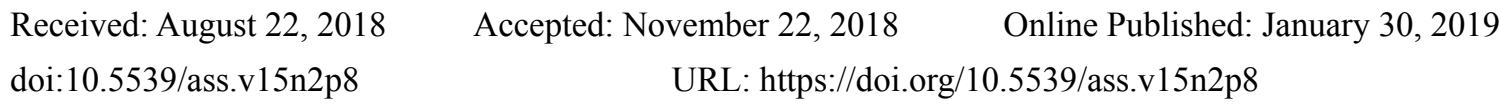

\begin{abstract}
Theory, strategy, learning method, technology, and curriculum of inclusive education for both regular children and children with special needs (CWSN) are changing from time to time. Teachers require In-Service Training (IST) which enables them to adapt to these changes. One of the alternative ways for teachers who were already employed to obtain a new development access in education and educational technologies is to get IST. This research aimed to classify the teachers' competence in inclusive schools based on their participation in the In-Service Training program of inclusive education. The research subjects were the 38 inclusive school teachers, taken by purposive random sampling. The data was collected by using questionnaire and analyzed by using descriptive and parametric statistic. The results reveal that there was a significant difference in pedagogic competence of teachers based on their participation in the In-Service Training (IST) program of inclusive education. The more often the teachers participate in the In-Service Training program, the better their pedagogic competence can be.
\end{abstract}

Keywords: teachers' competence, inclusive school, in-service training

\section{Introduction}

Inclusive education is an education system which provides a great amount of opportunities for all learners with special needs, however are potentially bestowed with special intelligence and / or talent that enable them to be equalized in enjoying common educational environment along with general students. (Gearheart, 1976; Ministry of Education, 2009; Charema, 2010; Sunardi, 2011; Salim, 2016). In Indonesia, the implementation of inclusive education significantly aimed at overcoming the limited number of the existing special schools for special schools are proven to have been able to educate around $1 \%$ of children with special needs (CWSN) which aims to accelerate the achievement of the CWSN compulsory education program (Ministry of Education and Culture, 2016).

Inclusive education in Indonesia was initially programmed since 2003. In 2016, there are 2,100 inclusive schools (Ministry of Education and Culture, 2016). The large number of inclusive schools has not been complemented by the quality of education services since most teachers in inclusive schools have limited competence to educate CWSN. The formal education background of the teachers are non-special education graduates (Yusuf, 2014), consequently their competency of pedagogic, professional, social and personality in inclusive schools have not fulfilled the criteria as professional teachers in inclusive schools to educate regular children and CWSN (Yusuf, 2014a; Salim, 2015).

Teachers in inclusive schools are required to increase their competence in educating the CWSN (Gunarhadi, 2016). In addition, theories, teaching strategies, teaching methods, technology and curriculum also change and develop over time. Teachers need training and refreshment to adapt to changes and advances in science and technology (Demirtaş, 2010; Charema, 2010; Celik, 2011). One way for teachers to obtain access to new developments in education and educational technology is to participate in an in-service training program (IST). According to the results of many research, the quality of schools and the quality of school graduates depends largely on teachers and teacher professional development (Fendler, 2003; Borko, 2004; Balta, 2015). With IST program, it gives impacts for teachers on positive development and student learning success (Castillo, Fernández-Berrocal, \& Brackett, 2013).

Since 2013, regular schools in Indonesia have attempted to implement the 2013 curriculum, including regular 
schools providing services and educational access to children with special needs (CWSN) and they are called inclusive schools. Teachers need socialization of the implementation of curriculum 2013 and also how to implement the curriculum for CWSN (Kuntarto, 2014). The need for the 2013 curriculum socialization program and the strategy of adapting the regular curriculum to CWSN are sophisticated issues that need to be addressed in inclusive schools.

This condition has also happened in many of the developing countries such as in Malaysia (Manisah, 2006), Northern Ireland (Lambe, 2007), Serbia (Kalyva, 2007), Dubai (Gaad \& Khan, 2007), and some other developing countries such as Russia (Shchipanova, 2016; Zvoleyko, 2013). Many aspects have not been fulfilled so that schools could not implement inclusive education as they should (Munawir, 2014) such as (1) the institutional aspect; (2) curriculum and learning, (3) student, (4) human resources, (5) facilities and infrastructure, (6) community participation, and (7) financing aspect. Due to the existence of the inclusive education movement in Indonesia, many IST programs have been served for teachers in inclusive schools, related to the 2013 curriculum and its implementation as well as strategies for adapting the curriculum and learning and assessment of CWSN in inclusive schools. How is the competence of teachers in inclusive schools viewed from their participation in IST program? The answer will be found by looking at the result of this research.

\section{Method}

\subsection{Participants}

The number of sample subjects were 38 teachers of inclusive schools, consisting of 27 people $(71 \%)$ female teachers and $11(29 \%)$ male teachers. They were selected by purposive random sampling, consisting of 24 people $(63.2 \%)$ of primary school teachers, 10 people $(26.3 \%)$ of junior high school teachers and $4(10.5 \%)$ of high school teachers in Central Java province.

Research subjects are required to have (a) at least 5 years of experience as a teacher, (b) have an interest in teaching a children with special education in public schools, (c) having assignment / appointment letter as special teacher / mentor from the Regional Educational Service 'Dinas Pendidikan Daerah'/ City, (d) are willingly to participate in a series of activities in this research.

\subsection{Measurement}

There are two data exposed in this study, namely the data of (1) teachers' pedagogic competency and (2) needs of inclusive education training according to teachers. Teachers' pedagogic competency is measured by using the indicator of Peraturan Menteri Pendidikan Nasional Republik Indonesia Number 16 Year 2007 About Academic Qualification and Teacher Competency Standards. The indicators include:

Table 1. Indicators of pedagogic competence mastery

\begin{tabular}{llc}
\hline Pedagogic competence & \multicolumn{1}{c}{ Indicator } & Total item \\
\hline & Mastering learning theories and learning principles. & 4 \\
& Developing a curriculum related to subjects that are taught. & 3 \\
& Organizing learning that educates. & 3 \\
& Utilizing information and communication technology for the benefit of learning. & 2 \\
& Facilitating potential development to actualize various possessed potentials. & 2 \\
& Communicating effectively, empathetically, and courteously with learners. & 1 \\
& Organizing assessment and evaluation of learning process and outcomes. & 4 \\
& Utilizing assessment results for learning purposes. & 1 \\
& Performing reflective actions to improve the quality of learning. & 1 \\
\hline
\end{tabular}

The data was collected by using closed questionnaire as the research instrument with 5 assessment scales (Likert's scale) starting from point 0 to point 4 . For favorable statement, point 0 was for highly not mastered and point 4 was for highly mastered. Meanwhile, for unfavorable statement, point 0 was for highly mastered and point 4 was for highly not mastered. Measurement was administered to determine self-assessment of pedagogic competence mastery of teachers.

Field trials of the instrument were conducted before using the questionnaire. It was found from the results of data 
analysis that there were 23 valid and 2 invalid items with the reliability coefficient of 0.910 and $\mathrm{P}$ of 0.000 . So it can be concluded that 23 statements developed are reliable.

In term of data on teacher needs for the need of inclusive education training, teachers are given a list of training themes that teachers may need. Teachers choose the available answer options by cross-marking $(\mathrm{x})$ on the selected answer option.

Table 2. Training themes offered

\begin{tabular}{|c|c|c|c|c|c|}
\hline \multirow{2}{*}{ No. } & \multirow{2}{*}{ Inclusive Education Training Theme } & \multicolumn{4}{|c|}{ Answer option*) } \\
\hline & & hi & I & $\mathrm{u}$ & $\mathrm{Hu}$ \\
\hline 1. & Definition of children with special need & & & & \\
\hline 2. & Causes of disability & & & & \\
\hline 3. & Type of children with special need & & & & \\
\hline 4. & Classification of handicapped CWSN & & & & \\
\hline 5. & Classification of intellectual disability & & & & \\
\hline 6. & Classification of Attention Deficit Hyperactive Disorder & & & & \\
\hline 7. & Characteristic of children with special need & & & & \\
\hline 8. & Obstacles faced by CWSN & & & & \\
\hline 9. & Identification of CWSN & & & & \\
\hline 10. & Development of identification tool & & & & \\
\hline 11. & Implementation of formal assessment & & & & \\
\hline 12. & Implementation of informal assessment & & & & \\
\hline 13. & Modification of learning goals & & & & \\
\hline 14. & Modification of learning materials & & & & \\
\hline 15. & Modification of learning process & & & & \\
\hline 16. & Individual Learning Program & & & & \\
\hline 17. & Learning strategy for CWSN & & & & \\
\hline 18. & Learning evaluation of CWSN & & & & \\
\hline 19. & Regulation of the Minister of National Education number 70 year 2009 & & & & \\
\hline 20. & Special teachers' duty in inclusive school & & & & \\
\hline 21. & Organization of inclusive class & & & & \\
\hline
\end{tabular}

Note: hi = highly important; $\mathrm{i}=$ important; $\mathrm{u}=$ unimportant; hu = highly unimportant

\subsection{Procedure}

The research subjects were gathered in one place on socialization activities of inclusive education for teachers, Central Java Province. After the opening ceremony was over, teachers were asked to fill in the questionnaire for 20 minutes and then the questionnaire was collected for analysis.

\subsection{Data Analysis}

The data was analyzed by using descriptive statistics and statistic parametric to describe the competence of teachers about teachers' competency analysis viewed from the participation in inclusive education training.

\section{Result and Discussion}

\subsection{Result}

Teachers Competence Level at Inclusive School

\subsection{Research Data}

The results of data collection of inclusive school teacher competency at primary, junior and senior high schools are as follows: 
Table 3. The achievement score of teacher pedagogic competence in inclusive schools

\begin{tabular}{|c|c|c|c|}
\hline Subject & $\begin{array}{l}\text { Achievement score of pedagogic } \\
\text { competence }\end{array}$ & $\begin{array}{l}\text { Participating in inclusive education training } \\
\text { frequency }\end{array}$ & Criteria \\
\hline 1 & 70 & 1 & Good \\
\hline 2 & 74 & 0 & Good \\
\hline 3 & 64 & 1 & Good \\
\hline 4 & 88 & 3 & Very Good \\
\hline 5 & 56 & 0 & Fair \\
\hline 6 & 58 & 1 & Fair \\
\hline 7 & 58 & 0 & Fair \\
\hline 8 & 48 & 0 & Fair \\
\hline 9 & 71 & 1 & Good \\
\hline 10 & 73 & 1 & Good \\
\hline 11 & 73 & 0 & Good \\
\hline 12 & 59 & 0 & Fair \\
\hline 13 & 44 & 0 & Fair \\
\hline 14 & 79 & 1 & Good \\
\hline 15 & 42 & 0 & Fair \\
\hline 16 & 52 & 0 & Fair \\
\hline 17 & 54 & 0 & Fair \\
\hline 18 & 40 & 0 & Poor \\
\hline 19 & 40 & 0 & Poor \\
\hline 20 & 44 & 0 & Fair \\
\hline 21 & 56 & 0 & Fair \\
\hline 22 & 70 & 1 & Good \\
\hline 23 & 54 & 0 & Fair \\
\hline 24 & 71 & 1 & Good \\
\hline 25 & 69 & 1 & Good \\
\hline 26 & 69 & 1 & Good \\
\hline 27 & 69 & 1 & Good \\
\hline 28 & 71 & 1 & Good \\
\hline 29 & 77 & 2 & Good \\
\hline 30 & 53 & 1 & Fair \\
\hline 31 & 46 & 0 & Fair \\
\hline 32 & 55 & 0 & Fair \\
\hline 33 & 61 & 1 & Good \\
\hline 34 & 50 & 0 & Fair \\
\hline 35 & 61 & 1 & Good \\
\hline 36 & 59 & 0 & Fair \\
\hline 37 & 74 & 2 & Good \\
\hline 38 & 85 & 3 & Very Good \\
\hline
\end{tabular}

\subsection{Descriptive Statistical Analysis}

Based on the data above, it was then conducted descriptive statistical analysis by using SPSS 20. It was obtained result as follows.

Table 4. Result of descriptive analysis of teacher pedagogic competence in inclusive school

\begin{tabular}{lllll}
\hline \multicolumn{5}{c}{ Descriptive Statistics } \\
\hline N & Mean & $\begin{array}{l}\text { Std. } \\
\text { Deviation }\end{array}$ & Minimum & Maximum \\
\hline Pedagogy 38 & 61,50 & 12,580 & 40 & 88 \\
\hline
\end{tabular}

The result of descriptive statistic above showed that from 38 teachers, it was obtained that the mean of pedagogic 
competence was 61.50, the lowest (minimum) score was 40, and the highest (maximum) score was 88 .

\subsection{Data Normality Test}

To determine whether the teacher pedagogic competence is meaningful or not in terms of differences in frequency of inclusion education training, parametric statistical technique of Anova one-way test was employed. However, before the parametric test was applied, normality and homogeneity test were applied.

The result of data normality test of teacher pedagogic competence of inclusive education was:

Table 5. Visualization of data normality test result by using Kolmogorov-Smirnov test

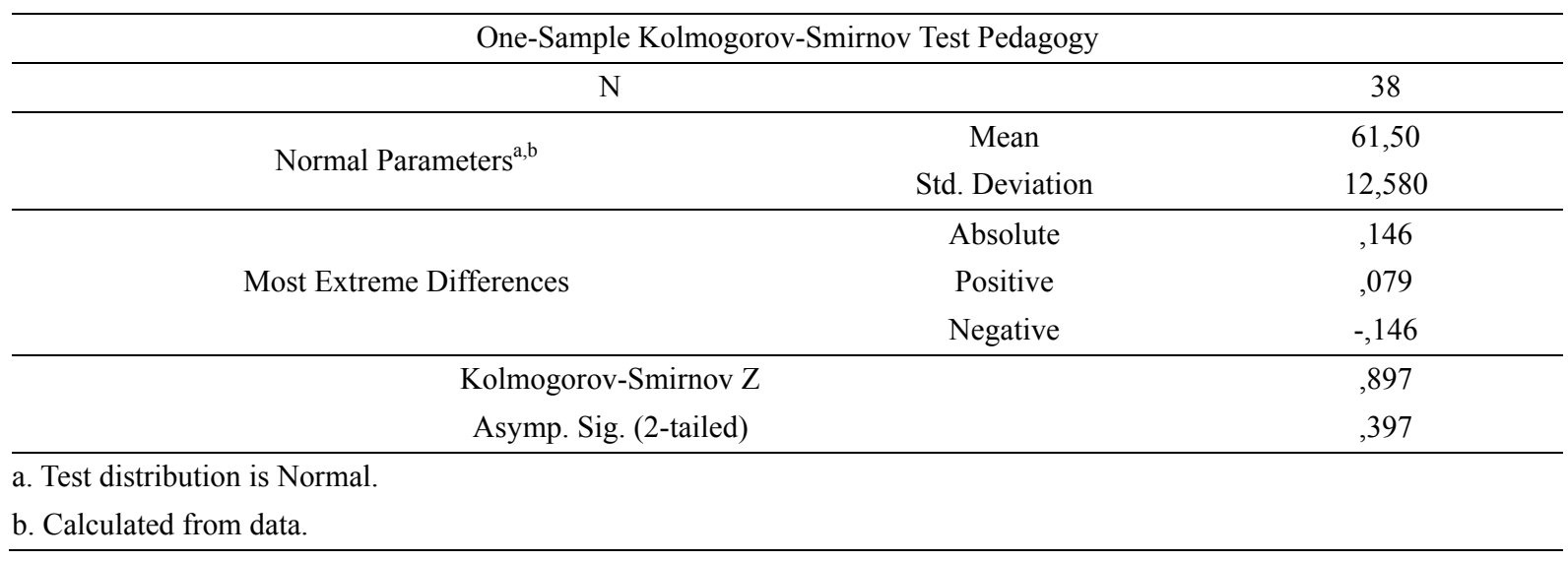

Based on the table above, it shows that the value of $z=0.897$ with $p=0.397(P=$ Value $0.397>0.05)$. It is concluded that data is normally distributed.

\subsection{Homogeneity Test}

The next step as precondition test of parametric statistic test was employing data homogeneity test as follows.

Table 6. Visualization of data homogeneity test result

\begin{tabular}{cccc}
\hline \multicolumn{4}{c}{ Test of Homogeneity of Variances } \\
\hline \multicolumn{4}{c}{ Pedagogy } \\
\hline Levene Statistic & df1 & df2 & Sig. \\
, 799 & 2 & 35 &, 458 \\
\hline
\end{tabular}

Based on the data above, it shows that the value was 0.799 with $p=0.458$. Since P-Value $0.458>0.05$, it can be said that the data was obtained from homogeny sample.

\subsection{Parametric Statistic Test}

Parametric statistical analysis of pedagogical competence data of inclusive education teacher or CWSN teacher in regular school is as follows:

Table 7. Visualization of Anova one Way test of Teacher Pedagogic Competency

\begin{tabular}{cccccc}
\multicolumn{7}{c}{ Anova One Way Test } \\
\hline \multicolumn{7}{c}{$\begin{array}{c}\text { ANOVA } \\
\text { Pedagogy }\end{array}$} \\
\hline Sum of Squares & Df & Mean Square & F & Sig. \\
\hline Between Groups & 3444,040 & 2 & 1722,020 & 24,993 & 0,000 \\
Within Groups & 2411,460 & 35 & 68,899 & & \\
Total & 5855,500 & 37 & & \\
\hline
\end{tabular}

Based on Anova One Way test result above, it can be seen that the value of $\mathrm{F}=24.993$ with $\mathrm{P}(\mathrm{P}$-value $)=0.000$. It can be concluded that there was a significant difference in teacher pedagogic competence based on the participation of inclusive education training. 
Table 8. The mean difference at the 0.05 level

\begin{tabular}{|c|c|c|c|c|c|c|c|}
\hline Depend & ent Variab & ole: $\mathrm{Pe}$ & $\begin{array}{l}\text { Multiple Co } \\
\text { lagogy }\end{array}$ & nparisons & & & \\
\hline & $\begin{array}{r}\text { (I) } \\
\text { Intenc }\end{array}$ & $\begin{array}{r}(J) \\
\text { Inten }\end{array}$ & $\begin{array}{r}\text { Mean } \\
\text { Difference }\end{array}$ & $\begin{array}{l}\text { Std. } \\
\text { Error }\end{array}$ & Sig. & $95 \% \mathrm{Co}$ & nfidence \\
\hline & ity & city & (I-J) & & & $\begin{array}{l}\text { Lower } \\
\text { Bound } \\
\end{array}$ & $\begin{array}{l}\text { Upper } \\
\text { Bound }\end{array}$ \\
\hline & 0 & 1 & $-14,425^{8}$ & 2,867 &, 000 & $-21,44$ & $-7,41$ \\
\hline & 0 & 2 & $-28,158^{*}$ & 4,566 &, 000 & $-39,33$ & $-16,98$ \\
\hline Tukey & & 0 & $14,425^{*}$ & 2,867 &, 000 & 7,41 & 21,44 \\
\hline $\mathrm{HSD}$ & 1 & 2 & $-13,733^{\circ}$ & 4,671 &, 016 & $-25,16$ & $-2,30$ \\
\hline & & 0 & $28,158^{*}$ & 4,566 &, 000 & 16,98 & 39,33 \\
\hline & 2 & 1 & $13,733^{8}$ & 4,671 &, 016 & 2,30 & 25,16 \\
\hline & 0 & 1 & $-14,425^{8}$ & 2,867 &, 000 & $-20,24$ & $-8,60$ \\
\hline & & 2 & $-28,158^{*}$ & 4,566 &, 000 & $-37,43$ & $-18,89$ \\
\hline & 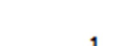 & 0 & $14,425^{*}$ & 2,867 &, 000 & 8,60 & 20,24 \\
\hline LSD & 1 & 2 & $-13,733^{\circ}$ & 4,671 &, 006 & $-23,22$ & $-4,25$ \\
\hline & 2 & 0 & $28,158^{*}$ & 4,566 &, 000 & 18,89 & 37,43 \\
\hline & 2 & 1 & $13,733^{\circ}$ & 4,671 &, 006 & 4,25 & 23,22 \\
\hline
\end{tabular}

The result showed that there was a statistically significant difference in teacher pedagogic competence in terms of the frequency of their participation in inclusive education training.

\section{The need for teacher inclusive education training}

The results of the research have been developed to determine the level of teacher needs in inclusive education training for the future. The result was obtained as follows:

Table 9. Teacher needs in inclusive education training

\begin{tabular}{ccc}
\hline Training Needs & Total & Percentage \\
\hline Highly Important & 23 & $61 \%$ \\
Important & 14 & $37 \%$ \\
Unimportant & 0 & $0 \%$ \\
Highly Unimportant & 1 & $3 \%$ \\
\hline Total & 38 & $100 \%$ \\
\hline
\end{tabular}

Based on the table above, the needs of teachers in training on inclusive education can be broken down into some parts, $61 \%$ states that it was very important, $37 \%$ important, and $3 \%$ highly unimportant. The data can be presented in the diagram below:

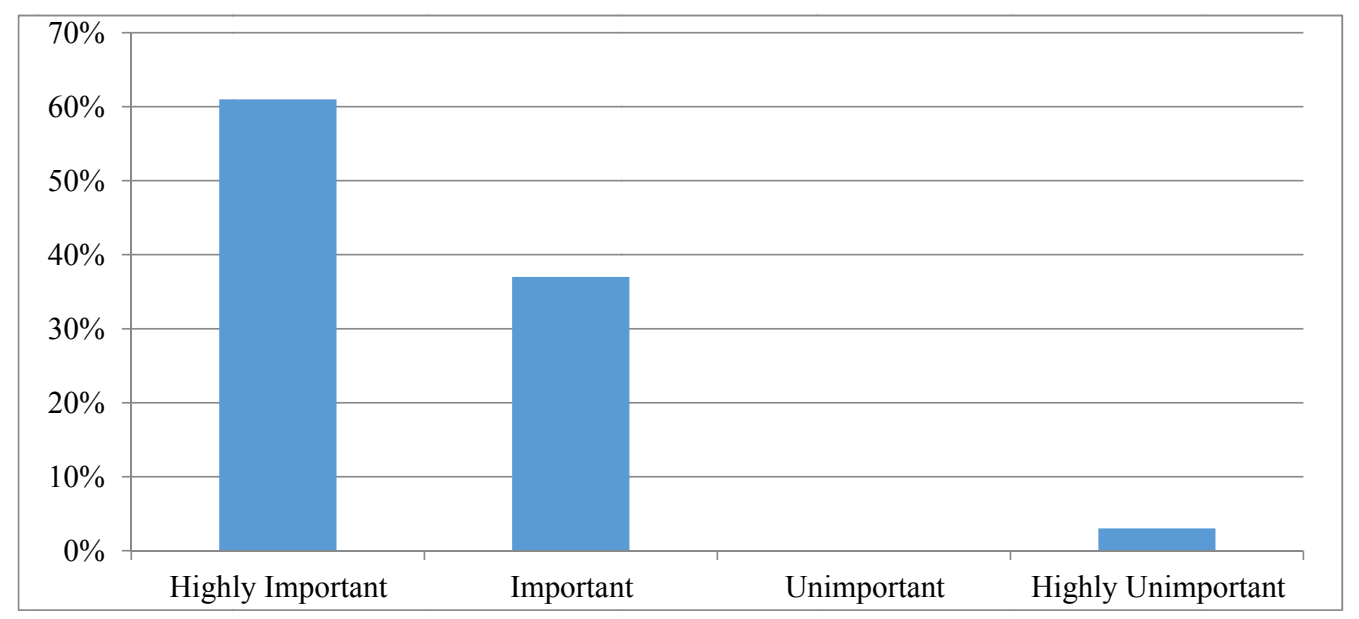


If it was reviewed deeper, this study identified the need for inclusive education training materials. It was elaborated as follows.

1) The concept of children with special needs (CWSN)

2) Types of children with special need,

3) Characteristics of children with special need,

4) Identification of CWSN,

5) Adapted curriculum for CWSN,

6) Individual Learning Program,

7) Learning strategy for CWSN,

8) Evaluation of CWSN learning,

9) Regulation of the Minister of National Education No. 70 of 2009,

10) Understanding of full inclusion and segregation, and

11) The assignment of special teachers in inclusive schools.

\section{Discussion}

Teachers who have participated in the inclusion education training have better pedagogic competence than those who have not participated. Similarly, teachers, who have more training frequency, will have better pedagogic competence, whether related to the mastery of the theory, as well as the skills to educate the CWSN.

The result is in line with theory of Kurt Lewin (1961) about "Field Theory". Lewin states that behavior is the result of two sets of forces working constantly against each other either in the individual or in the independent situation. Change forces produce pressure to move toward a desired goal, resisting forces produce pressure to resist the driving forces. When driving force are strong and retraining forces weak, behavior will be toward attaining the goal.

The implementation of this behavior change theory is that teachers who participate in the training can improve their conceptual understanding, skills and have positive attitude towards inclusive education and CWSN. Thus, all teachers who educate CWSN in regular schools should be prepared in such a way, both in pre-service training and in-service training programs so that teachers are ready to educate CWSN and can engage together with other teachers in schools. McKenzie (2009) states that in the USA where the history of inclusion is over three decades old, current special educator's professional standards clearly expect that certified special educators will enter the field with adept collaboration and co-teaching skills in order to optimize services for students with disabilities in inclusive settings. Coursework in collaboration for pre-service or in-service special educators is a common mechanism for providing this training within the United States.

The result of this study is in line with Arthaud's (2007) study of a partnership between general and special education, Friend and Cooks' (2009) on pedagogical competence training through collaboration training between special teachers and regular teachers in teaching CWSN at inclusive school. Balta (2015) on the effect of in-service training courses on teacher achievement: a meta-analysis study. Birman (2000) on designing of teacher's professional development, also in line with Blank's (2010) research on the effects of teacher professional development on gains in student achievement: how meta-analysis provides scientific evidence useful to education leaders.

Friend and Cooks (2009) require the cooperation of special education teachers with general school teachers, namely (a) collaboration is based on mutual goals, (b) collaboration partnerships on shared responsibility, (c) collaborative partners share resources, and (d) collaboration includes shared accountability for students with special needs (p. 911). The result of this study is also in line with the result of research from Mastropieri (2005) and research from Scruggs (2007). Conclusion can be drawn that with IST for inclusive school, teachers can improve their pedagogical competence.

\section{Conclusion}

Based on the results of the study, it can be concluded that (1) there is a significant difference in pedagogical competence of teachers based on their participation in inclusive education In-Service Training programs that have been attended. Teachers, who have more training frequency, will have better pedagogic competence. (2) The teacher's needs in the inclusive education in-service training program showed that $61 \%$ teachers state that it is highly important, 37\% important, and 3\% highly unimportant, (3) In-service training materials considered 
important by teachers include: (a The concept of CWSN (b) Type of the concept of children with special needs, (c) the characteristics of the concept of children with special needs, (d) Identification of CWSN, (e) adapted curriculum for CWSN, (f) Individual Learning Program, (g) learning strategies for CWSN, (h) CWSN learning evaluation, (i) inclusive education regulation, (j) full inclusion and segregation concepts, and (k) special teachers' duty in inclusive schools.

\section{References}

Arthaud, T. J., Arram, R. J., Breck, S. E., Doelling, J. E., \& Bushrow, K. M. (2007). Developing collaboration skills in pre-service teachers: A partnership between general and special education. Teacher Education and Special Education, 30(1), 1-12. https://doi.org/10.1177/088840640703000101

Balta, N., Arslan, M., \& Duru, H. (2015). The Effect of In-Service Training Courses on Teacher Achievement: A Meta-analysis Study. Journal of Education and Training Studies, 3(5), 254-263. https://doi.org/10.11114/jets.v3i5.1037

Birman, B. F., Desimone, L., Porter, A. C., \& Garet, M. S. (2000). Designing professional development that works. Educational Leadership, 57(8), 28-33. Retrieved from http://www.ascd.org/ASCD/pdf/journals/ ed_lead/el200005_birman.pdf

Blank, R. K., \& Alas, N. L. (2010). Effects of Teacher Professional Development on Gains in Student Achievement: How Meta-Analysis Provides Scientific Evidence Useful. Education Leaders. 2010 SREE Conference Abstract Template.

Borko, H. (2004). Professional Development and teacher learning: Mapping the terrain. Educational Researcher, 33(8), 3-15. https://doi.org/10.3102/0013189X033008003

Castillo, R., Fernández-Berrocal, P., \& Brackett, M. A. (2013). Enhancing teacher effectiveness in Spain: A pilot study of the ruler approach to social and emotional learning. Journal of Education and Training Studies, 1(2), 263-272. https://doi.org/10.11114/jets.v1i2.203

Celik, S. (2011). Characteristics and Competencies for Teacher Educators: Addressing the Need for Improved Professional Standards in Turkey. Australian Journal of Teacher Education, 36(4). https://doi.org/10.14221/ajte.2011v36n4.3

Charema, J. (2010). Inclusive Education in Developing Countries in the Sub Saharan Africa: From Theory to Practice. International Journal of Special Education, 25(1), 87-93.

Demirtaş, Z. (2010). As a tool for training teacher in service, supervision. Electronic Journal of Social Sciences, 9(31), 41-52.

Fendler, L. (2003). Teacher reflection in a hall of mirrors: historical influences and political reverberations. Educational Researcher, 32(3), 16-25. https://doi.org/10.3102/0013189X032003016

Friend, M., \& Cook, L. (2009). Interactions: Collaboration skills for school professionals (5th ed.). Boston: Pearson Education, Inc.

Gaad and Khan. (2007). Primary Mainstream Teachers' Attitude towards Inclusion of Students with Special Educational Needs in the Private Sector: A Perspective from Dubai. International Journal of Special Education, 22(2), 95-114. Retrieved from https://files.eric.ed.gov/fulltext/EJ814493.pdf

Gearheart, W. (1976). The Handicapped Child in the Regular Classroom. Saint Louis: The CV. Mosby Co.

Gunarhadi. (2016). The effect of Cluster-Based Instruction on Mathematic Achievement in Inclusive Schools. International Journal of Special Education, 31(1), 78-87. Retrieved from https://files.eric.ed.gov/fulltext/EJ1099973.pdf

Kalyva, E., Gojkovic, D., \& Tsakiris, V. (2007). Serbian Teachers' Attitudes towards Inclusion. International Journal of Special Education, 22(1), 30-37.

Kuntarto, E. D. (2014). Kajian Implementasi Kurikulum 2103 Pada Pembelajaran Calistung Di Sekolah Dasar. Jambi: Program Studi Pendidikan Guru Sekolah Dasar.

Lambe, J. (2007). Northern Ireland Student Teachers' Changing Attitudes towards Inclusive Education during Initial Teacher Training. International Journal of Special Education, 22(1), 56-76. Retrieved from https://files.eric.ed.gov/fulltext/EJ814470.pdf

Lewin, K. (1961). Resolving Social Conflicts: Quasi-Stationary Social Equilibria and the Problem of Permanent Change in the Planning of Change (pp. 235-238). 
Manisah, M. R., \& Jelas, Z. M. (2006). An Empirical Study on Teachers' Perceptions towards Inclusive Education in Malaysia. International Journal of Special Education, 21(3).

Mastropieri, M. A., Scruggs, T. E., Graetz, J., Norland, J., Gardizi, W., \& McDuffe, K. (2005). Case studies in co-teaching in the content areas: Successes, failures, and challenges. Intervention at School and Clinic, 40, 260-270. https://doi.org/10.1177/10534512050400050201

McKenzie, R. G. (2009). A national survey of pre-service preparation for collaboration. Teacher Education and Special Education, 32, 379-393. https://doi.org/10.1177/0888406409346241

Ministry of Education and Culture, Center for Educational Data and Statistics and Culture. (2016). Indonesia Educational Statistics in Brief 2015/2016. Retrieved July 21, 2017, from http://publikasi.data.kemdikbud.go.id/uploadDir/isi_AA46E7FA-90A3-46D9-BDE6-CA6111248E94_.pdf

Regulation of the Ministry of National Education. (2009). Inclusive education for children with disabilities and intelligent children / special talents.

Salim, A. (2015). The Mastery of Pedagogic Competency among the Teachers of Special School in Surakarta Area. Proceeding (pp. 235-241). International Seminar on Society Empowerment. Mercubuana University.

Salim, A. (2016). Effectiveness of Modified Curriculum and Instruction to Improve Learning Achievement in Social Science Among Children with Potential Intellectual limitation in Inclusive Elementary Schools. Proceeding: International Conference on Special Education in Southeast Asia Region (pp. 189-193). Kualalumpur: National University of Malaysia.

Scruggs, T. E., Mastropieri, M. A., \& McDuffie, K. A. (2007). Co-teaching in inclusive classrooms: A metasynthesis of qualitative research. Exceptional Children, 73, 392-416. https://doi.org/10.1177/001440290707300401

Shchipanova, D. Y., Tserkovnikova, N. G., Uskova, B. A., Puzyrev, V. V., Markova, A. S., \& Fomin, E. P. (2016). Hardiness of Adolescents with Special Educational Needs: Research Results. International Journal of Environmental \& Science Education, 11(17), 9829-9838.

Sunardi, M., Gunarhadi, P., \& Yeager, J. L. (2011). The implementation of inclusive education for students with special needs in Indonesia. Excellence in Higher Education, 2, 1-10. https://doi.org/10.5195/EHE.2011.27

Yusuf, M. (2014a). Evaluasi Diri Sekolah Inklusif. Surakarta: Tiga Serangkai.

Yusuf, M. (2014b). Manajemen Sekolah Berbasis Pendidikan Inklusif. Surakarta: Tiga Serangkai.

Zvoleyko, E. V., Kalashnikova, S. A., \& Klimenko, T. K. (2013). Socialization of students with disabilities in an inclusive educational environment. International Journal of Environmental \& Science Education, 11(14), 6469-6481. Retrieved from https://files.eric.ed.gov/fulltext/EJ1115873.pdf

\section{Copyrights}

Copyright for this article is retained by the author(s), with first publication rights granted to the journal.

This is an open-access article distributed under the terms and conditions of the Creative Commons Attribution license (http://creativecommons.org/licenses/by/4.0/). 